\title{
The Mycotoxins - 4-Deoxynivalenol, Zearalenone and Aflatoxin - in Weather-damaged Wheat Harvested 1983-1985 in South-eastern Queensland
}

\author{
B. J. Blaney, C. J. Moore and A. L. Tyler
}

Queensland Department of Primary Industries,

Animal Research Institute, Yeerongpilly, Qld 4105.

\begin{abstract}
A survey for various mycotoxins was carried out on samples of all wheat delivered to nine storage and marketing depots in south-eastern Queensland, selected as most likely to receive mycotoxin-contaminated grain. All wheat was surveyed during 1983, when the degree of weather damage was high. Samples of the poorest grade of wheat from these depots were also surveyed in 1984 and 1985. The surveys included all regions where head scab of wheat caused by Fusarium graminearum Schwabe Group 2 had been reported to occur at significant levels. 4-Deoxynivalenol was detected in nearly all pooled samples representing bulk wheat at concentrations ranging from traces of $<0.01 \mathrm{up}$ to $1.7 \mathrm{mg} \mathrm{kg}^{-1}$. The highest concentration of zearlenone detected in a pooled wheat sample was $0.04 \mathrm{mg} \mathrm{kg}^{-1}$. In a few samples representing individual wheat deliveries and with up to $2.8 \%$ by weight of pink grains, 4-deoxynivalenol concentrations ranged up to $11.7 \mathrm{mg} \mathrm{kg}^{-1}$ and zearalenone up to $0.43 \mathrm{mg} \mathrm{kg}^{-1}$. Aflatoxins $\mathrm{B}_{1}, \mathrm{~B}_{2}, \mathrm{G}_{1}$ and $\mathrm{G}_{2}$ were detected in only one pooled sample of wheat, at a total aflatoxin concentration of $0.003 \mathrm{mg} \mathrm{kg}{ }^{-1}$. Ochratoxin A, sterigmatocystin and T-2 toxin were not detected. Higher concentrations of mycotoxins were found in the poorer grades of wheat.
\end{abstract}

\section{Introduction}

Grain crops infected by Fusarium graminearum Schwabe can contain various mycotoxins, including zearalenone (ZEA) and trichothecenes. Diseases in humans and domestic animals caused by consumption of infected grain and characterized by oestrogenic effects, emesis, feed refusal and haemorrhagic syndromes have been reported in Japan and Korea (Yoshizawa 1983), and similar diseases occur in other countries. In North America, several epidemics in domestic animals have been caused by $F$. graminearum-infected wheat and maize (Scott 1983; Vesonder 1983). The main impact has been on the pig industry, since pigs are more sensitive than some other species to ZEA (a pseudo-oestrogen) and 4-deoxynivalenol (DON, an emetic and feed refusal agent). These are two of the most common mycotoxins produced by $F$. graminearum in North America. Other trichothecenes, such as T-2 toxin, diacetoxyscirpenol and nivalenol, also produced by $F$. graminearum, may be involved in haemorrhagic syndr aes, but have not been surveyed in field crops as extensively as DON.

In eastern Australia, one of the important diseases of wheat is crown rot, caused by $F$. graminearum Group 1 (Burgess et al. 1981). Members of $F$. graminearum Group 1 are adapted to dryland survival, rarely form perithecia in nature and so rarely affect the wheat grain (Francis and Burgess 1977). On the other hand, members of F. graminearum Group 2 form perithecia freely and attack aerial parts of plants, causing head scab and ear and stalk-rots of maize. Head scab of wheat is not significant in the main wheat growing regions of Australia, probably because maize is not grown there, and because conditions are usually dry during anthesis, the main period for infection by F. graminearum Group 2 (Burgess 1985).

In Queensland, maize and wheat are both grown in three regions of the south-east: the southern Darling Downs, the Burnett region and the Moreton region. Although only about 
$3 \%$ of Queensland's wheat is grown in these wetter regions, they often contribute proportionately more feed grain to the intensive pig and poultry industries of Queensland which are predominantly based in the south-east (Blaney 1984).

It was reported by Moore et al. (1985) that feed refusal by pigs due to DON had occurred during 1983 near Beaudesert, in the Moreton region of south-eastern Queensland. Unusually wet weather might have led to increased head scab in crops, but the extent of mycotoxin contamination was unknown. It was important that this be assessed, in order to determine the possible effects of using weather-damaged wheat on pig production, and also for general marketing purposes. Marketing of Australian wheat is controlled by the Australian. Wheat Board, and in Queensland, wheat may be held either on the farm of origin for feed or delivered to storage depots controlled by Bulk Grains Queensland (BGQ). While it was not practicable to obtain representative samples of all wheat held on farms, there was little reason to consider that the quality of that wheat would be markedly different from that of wheat delivered to $B G Q$ depots. Consequently, we investigated the degree of mycotoxin contamination of wheat delivered to BGQ depots in south-eastern Queensland during 1983, 1984 and 1985.

\section{Materials and Methods}

\section{Sampling and Physical Examination}

Samples of all wheat deliveries in Queensland are taken for official grading purposes by the State Wheat Board. These were the samples examined in this survey. Quality standards for the 1983-84 season, that were most pertinent to this survey, were as follows.

Australian Standard White (ASW): minimum density $740 \mathrm{~g} \mathrm{I}^{-1}$; no more than $100 \mathrm{l}^{-1}$ of foreign seeds; no more than $5 \%$ of unmillable material; nil sprouted grains, musty grains or certain foreign materials; up to $10 \%$ by count of weather-stained, black-pointed or fungus-affected, pink grains; up to $1 \%$ of drygreen, sappy, discoloured or distorted grains; maximum moisture content of $12 \%$.

Prime Hard $(\mathrm{PH})$ : Certain approved varieties of hard wheat, otherwise meeting ASW specifications, but allowing up to $15 \%$ mottled grain.

No. $1 \mathrm{Hard}(1 \mathrm{H})$ : as for $\mathrm{PH}$, but allowing up to $25 \%$ mottle grain.

No. 2 Hard $(2 \mathrm{H})$ : as for $\mathrm{PH}$, but minimum density of $710 \mathrm{~g} \mathrm{l}^{-1}$; up to $15 \%$ sprouted grain, up to $20 \%$ of weather stained, black pointed or fungus-affected, pink grains; up to $2 \%$ of dry-green, sappy or distorted grains; up to $7.5 \%$ unmillable material.

General Purpose (GP): wheat which is merchantable, but does not fit into ASW, $\mathrm{PH}, 1 \mathrm{H}$ or $2 \mathrm{H}$ categories: minimum density of $620 \mathrm{~g} \mathrm{l}^{-1}$; nil objectionable foreign material; maximum moisture content of $12 \%$.

In 1983, 1291 samples of wheat in ASW, PH, 1H, 2H and GP grades were examined. These represented all wheat delivered to BGQ depots at Forest Hill and Pinkenbah in Moreton region, at Warwick, Allora and Clifton on the southern Darling Downs, and at Byee, Kingaroy, Wooroolin and Gayndah in the Burnett region. In 1984 and 1985, only GP grade wheat from these depots was examined (60 and 80 samples respectively). Samples each weighed about $120 \mathrm{~g}$, and were stored in brown paper packets for 9 months at ambient temperatures before examination. The location of wheatgrowing farms was approximated where possible from mailing addresses of farmers and from telephone directories.

All samples from 1983 and 1984 were examined for the presence of grains with a pink discolouration. Pink grains were separated and weighed. Eleven samples from the 1983 harvest and two from the 1984 harvest were selected from samples with higher levels of pink grains in each district, and individually assayed. A few pink grains from each of 11 of these samples were examined for the presence of $F$. graminearum. Remaining samples were pooled according to grade and depot, and in some cases according to variety. In 1985, samples were not individually examined for pink grains before pooling.

Samples were hammer milled through a $1 \mathrm{~mm}$ screen and subsampled with a riffle divider.

\section{Mycotoxin Assays}

Samples were first assayed for aflatoxins $B_{1}, B_{2}, G_{1}, G_{2}$, ochratoxin A, sterigmatocystin, ZEA and T-2 toxin by thin layer chromatography (TLC) (Blaney et al. 1984a). All samples were then assayed by high performance liquid chromatography (HPLC) for ZEA (Blaney et al. 1984a).

DON was assayed by two methods, each having certain limitations. A HPLC method (Blaney et al. 1986) was used for samples with DON concentrations exceeding $0.5 \mathrm{mg} \mathrm{kg}^{-1}$. Although this method was 
the simpler, results were unreliable at lower concentrations due to interferences. The second method used capillary gas chromatography-mass spectrometry (GC-MS). This method was more definitive and sensitive, but less suitable for routine quantitative assay, and so was used for confirmation and estimation of DON at concentrations less than $0.5 \mathrm{mg} \mathrm{kg}^{-1}$. Both methods used the extraction procedure of Scott et al. (1981). In our hands, recoveries averaged $78 \%$ and the results quoted have been corrected by this figure.

The GC-MS instrumentation has been described previously (Moore et al. 1985). The original derivatization procedure, which involved trimethylsilylation, was replaced by an esterification procedure using pentafluoropropionic anhydride (PFPA) (Ware et al. 1984). This resulted in a cleaner extract being applied to the capillary column, causing much less damage to the column. While this derivative is suited primarily to detection by electron capture, its electron impact mass spectrum contains several fragments suitable for single ion monitoring. The dried extract was dissolved in $1 \mathrm{ml}$ of toluene containing $2 \mathrm{mg}$ 4-dimethylaminopyridine. From this, $0.5 \mathrm{ml}$ was transferred to a $2 \mathrm{ml}$ vial, to which $0.025 \mathrm{ml}$ PFPA was added, and the vial securely capped. After heating for $20 \mathrm{~min}$ at $60^{\circ} \mathrm{C}$, the vial was cooled, $0.5 \mathrm{ml}$ of $5 \%$ aqueous sodium bicarbonate was added, and the mixture was vigorously agitated for 1 min. After separation, an aliquot of the upper layer was dried over anhydrous sodium sulfate. Analysis was performed by splitless injection, with single ion monitoring of a fragment at 309 mass units. Quantification was performed by comparison of peak heights with those of standards.

\section{Results}

\section{Physical Examination}

Most samples in the GP grade and some in $2 \mathrm{H}$ had suffered severe weather damage as indicated by sprouted grain, shrunken grain, and the dark discolouration known as 'black point', caused mainly by Alternaria spp. of fungi (Rees et al. 1984). These were the most common reasons for the GP and $2 \mathrm{H}$ classifications. Smaller numbers had been down-graded for weed-seed contamination, light-weight grain, mottled and discoloured grain.

Of the 1291 samples delivered to these depots in 1983, 62 contained $>0.2 \%$ of pink grains. Of these, 60 were in GP grade and 2 in $2 \mathrm{H}$ grade. The distribution between depots and approximate location of farms growing these samples are given in Table 1 . The highest concentrations $(w / w)$ of pink grains were $2.4 \%$ and $1.4 \%$ in two samples from Pinkenba depot (grown at Innis Plain, south of Beaudesert), and $2.8 \%$ and $2.6 \%$ in two samples from Warwick depot (grown at Elbow Valley and Tannymorel). From the 1984 harvest, only two GP samples (grown near Boonah) from Pinkenba depot contained $>0.2 \%$ pink grains.

\section{Mycotoxin Assays}

One sample of GP, Cook variety wheat from Wooroolin depot, contained traces of aflatoxins $B_{1}, B_{2}, G_{1}$ and $G_{2}$ (total concentration $0.003 \mathrm{mg} \mathrm{kg}^{-1}$ ). Aflatoxins were not detected in the remaining samples $\left(<0.001 \mathrm{mg} \mathrm{kg}^{-1}\right)$. Ochratoxin $\mathrm{A}\left(<0.001 \mathrm{mg} \mathrm{kg}^{-1}\right)$, sterigmatocystin $\left(<0.02 \mathrm{mg} \mathrm{kg}^{-1}\right)$ and $\mathrm{T}-2$ toxin $\left(<0.1 \mathrm{mg} \mathrm{kg}^{-1}\right)$ were not detected in any sample. Compounds tentatively identified as alternariol and alternariol monomethyl ether, metabolites of Alternaria spp., were seen during TLC assay in about half of the wheat samples, but these were not positively identified, nor quantified. The compound alternariol monomethyl ether interferes with ZEA detection by TLC, but no problem is encountered during HPLC analysis.

Results of ZEA and DON assays are given in Tables 2, 3 and 4. Although high concentrations of ZEA and DON were present in samples with many pink grains, contamination was much lower in pooled wheat samples. Calculations indicate that the ZEA and DON concentrations in pooled samples would not have been significantly higher had the few samples withheld for individual assay been mixed into the pooled samples.

\section{Fungal Isolations}

F. graminearum was isolated from pink grains from selected samples (Table 2) from Lowood (two isolates), Innis Plain, Elbow Valley, Tannymorel, Allora, Kumbia and Boonah, but not from Coominya, Forest Hill, Home Creek and Binjour (R. L. Dodman, personal communi- 
cation). All isolates produced perithecia on carnation leaf agar (Tio et al. 1977) and so belong to $F$. graminearum Group 2.

\section{Discussion}

DON was detected in all samples except three, but concentrations in the pooled samples are very low relative to those known to cause ill effects in animals. Concentrations in ASW were much less than in GP and $2 \mathrm{H}$ grades, the maximum concentration in ASW being 0.05 $\mathrm{mg} \mathrm{kg} \mathrm{k}^{-1}$ in Forest Hill wheat. Canadian wheat containing less than $2 \mathrm{mg} \mathrm{kg}^{-1}$ of DON was tolerated by pigs, while poultry and cattle were less susceptible (Trenholm et al. 1984). Queensland wheat naturally contaminated with DON produced no adverse effects on pigs at a dietary level of $1.6 \mathrm{mg} \mathrm{DON} \mathrm{kg}{ }^{-1}$, but $4.4 \mathrm{mg} \mathrm{kg}^{-1}$ and higher, induced emesis and decreased performance (K. C. Williams, B. J. Blaney and M. H. Magee, unpublished data). Although only one sample of pooled wheat (GP Kite from Warwick depot in 1983) approached these concentrations, results should be interpreted cautiously, since the uniform mixing obtainable with the assay samples is not likely to be achieved in normal bulk grain handling, and concentrations of DON higher than those found here could be present in some portions of the grain. Wheat from Warwick depot also contained the highest DON concentration in 1985. Pooled wheat samples from Warwick, Forest Hill and Pinkenba depots contained the highest concentration of pink grains, while pooled samples from other depots contained $0.04 \%$ or less.

Table 1. The distribution of wheat samples containing more than $0.2 \%$ of pink grains between wheat depots, and the number and approximate locations of farms growing samples with more than $0.2 \%$ pink grains.

\begin{tabular}{|c|c|c|c|c|c|}
\hline \multirow[t]{2}{*}{ Depot } & \multirow[t]{2}{*}{$\begin{array}{l}\text { Wheat } \\
\text { grade }\end{array}$} & \multicolumn{2}{|c|}{ No. samples } & \multicolumn{2}{|c|}{$\begin{array}{l}\text { Farms growing samples } \\
\text { with }>0.2 \% \text { pink grains }\end{array}$} \\
\hline & & Total & $\begin{array}{l}>0.2 \% \text { pink } \\
\text { grains }\end{array}$ & No. & Locations \\
\hline Forest Hill & $\begin{array}{c}\text { GP } \\
2 \mathrm{H} \\
\mathrm{ASW}\end{array}$ & $\begin{array}{r}112 \\
66 \\
29\end{array}$ & $\begin{array}{r}22 \\
0 \\
0\end{array}$ & 10 & $\begin{array}{l}\text { Coominya, Forest Hill, } \\
\text { Lowood, Laidley, Thornton }\end{array}$ \\
\hline Pinkenba & $\begin{array}{c}\mathrm{GP} \\
\mathrm{PH}, 1 \mathrm{H}\end{array}$ & $\begin{array}{r}7 \\
37\end{array}$ & $\begin{array}{l}2 \\
0\end{array}$ & I & Innis Plain \\
\hline Warwick & GP & 65 & 19 & 6 & $\begin{array}{l}\text { Elbow Valley, Freestone, } \\
\text { Maryvale, Tannymorel, } \\
\text { West Talgai, Willowvale }\end{array}$ \\
\hline Allora & GP & 19 & 1 & 1 & Allora \\
\hline Clifton & GP & 102 & 3 & 2 & Back Plains, Nobby \\
\hline Byee & GP & 35 & 1 & 1 & Marshlands \\
\hline Kingaroy & $\begin{array}{c}\text { GP } \\
2 \mathrm{H} \\
\text { PH, 1H } \\
\text { ASW }\end{array}$ & $\begin{array}{r}127 \\
24 \\
27 \\
91\end{array}$ & $\begin{array}{l}0 \\
2 \\
0 \\
0\end{array}$ & 1 & Kumbia \\
\hline Wooroolin & $\begin{array}{c}\text { GP } \\
2 \mathrm{H} \\
\text { ASW }\end{array}$ & $\begin{array}{r}97 \\
13 \\
201\end{array}$ & $\begin{array}{l}7 \\
0 \\
0\end{array}$ & 3 & $\begin{array}{l}\text { Cushnie, Home Creek, } \\
\text { Wooroolin }\end{array}$ \\
\hline Gayndah & $\begin{array}{c}\text { GP } \\
2 \mathrm{H} \\
\mathrm{ASW}\end{array}$ & $\begin{array}{r}110 \\
105 \\
24\end{array}$ & $\begin{array}{l}5 \\
0 \\
0\end{array}$ & 2 & Binjour, unknown \\
\hline
\end{tabular}


Samples selected for individual assay contained from 0.1 to $2.8 \%$ pink grains and from 0.02 to $11.7 \mathrm{mg}$ DON kg-1. Although the five samples containing $>2 \mathrm{mg} \mathrm{DON} \mathrm{kg} \mathrm{m}^{-1}$ also contained $>1 \%$ pink kernels, appreciable DON concentrations were present in samples containing $0.2 \%$ pink kernels, while some with higher concentrations of pink kernels contained low DON levels. Consequently, the presence of pink grains is a useful indicator of the possible presence of DON, but concentrations of pink grains would be unreliable for monitoring of DON concentrations in bulk wheat. However, a case can be made for a tightening of wheat quality standards, perhaps to $0.2 \%$ pink grains, which should restrict DON levels to $<2 \mathrm{mg}$ $\mathrm{kg}^{-1}$. Up to $1 \%$ pink grains could probably be allowed in individual deliveries, given that substantial dilution is likely to occur during bulk grain handling.

Table 2. Concentrations of pink grains, zearalenone and 4-deoxynivalenol in selected wheat samples with higher concentrations of pink grains

\begin{tabular}{lccc}
\hline Farm location & $\begin{array}{c}\text { Pink } \\
\text { grains (\%) }\end{array}$ & $\begin{array}{c}\text { Zearalenone } \\
\left(\mathrm{mg} \mathrm{kg}^{-1}\right)\end{array}$ & $\begin{array}{c}\text { 4-Deoxynivalenol } \\
\left(\mathrm{mg} \mathrm{kg}^{-1}\right)\end{array}$ \\
\hline Coominya & \multicolumn{2}{c}{ Harvested 1983 } \\
Lowood & 0.2 & $\mathrm{~A}$ & 0.3 \\
Forest Hill & 0.5 & 0.04 & $0.7^{\mathrm{B}}$ \\
Innis Plain & 0.1 & $\mathrm{~A}$ & 0.02 \\
& 1.4 & 0.13 & $11.7^{\mathrm{B}}$ \\
Elbow Valley & 2.4 & 0.13 & $7.0^{\mathrm{B}}$ \\
Tannymorel & 2.6 & 0.19 & $8.3^{\mathrm{B}}$ \\
Allora & 2.8 & 0.43 & $8.1^{\mathrm{B}}$ \\
Kumbia & 0.5 & 0.02 & $1.9^{\mathrm{B}}$ \\
Home Creek & 0.2 & 0.01 & $1.1^{\mathrm{B}}$ \\
Binjour & 0.2 & $\mathrm{~A}$ & $0.2^{2}$ \\
& 0.5 & 0.01 & 0.02 \\
Boonah & \multicolumn{2}{c}{ Harvested 1984} & $0.5^{\mathrm{B}}$ \\
& 0.4 & 0.02 & $2.9^{\mathrm{B}}$ \\
\hline
\end{tabular}

A Zearalenone concentrations $<0.010 \mathrm{mg} \mathrm{kg}^{-1}$.

${ }^{\mathrm{B}}$ Assayed by HPLC method. Others assayed by GC-MS method.

Only small amounts of ZEA were found in the samples. Concentrations need to approach $1 \mathrm{mg} \mathrm{kg}^{-1}$ to affect young female pigs (Kurtz et al. 1969; Blaney et al. 1984b).

Although some fungi other than $F$. graminearum may produce a pink or red colour, there seems little doubt that the DON and ZEA were produced by this fungus. $F$. graminearum was isolated from those samples containing higher levels of DON. The failure to isolate the fungus from a few other samples may have been due to the long storage period between harvest and attempted isolations. It is common for mycotoxins to remain stable in dry grain, long after the producing fungus has lost viability. The isolates of $F$. graminearum produced substantial amounts of DON and ZEA in culture (B. J. Blaney and R. L. Dodman, unpublished data).

The regions where head scab (as indicated by higher concentrations of pink grains) appeared to occur most frequently from this survey were the foothills of the ranges east of Warwick and in the Laidley Valley, between Brisbane and Toowoomba. A third region was represented by Innis Plain and Boonah in this survey. This third region includes Beaudesert, where one sample of wheat contained about $20 \%$ of pink grains and $34 \mathrm{mg} \mathrm{DON} \mathrm{kg}^{-1}$ in 1983 (Moore et al. 1985). Another sample collected by a pig advisor in 1984 from Hillview contained $8 \%$ of pink grains and $11 \mathrm{mg}$ DON kg-1 (B. J. Blaney, unpublished data). The Innis Plain-BoonahBeaudesert-Hillview region lies just across the Queensland-New South Wales border ranges from the Kyogle-Ettrick-Casino-Tabulan region where a high frequency of head scab was also seen in 1983 (B. Clarke, personal communication). All of these regions have a similar topography, 
and lie near to the approaches to ranges. The main factor contributing to head scab is the rotation of wheat with maize, possibly combined with higher humidity and rainfall due to the proximity to ranges.

The trace of aflatoxin found in one sample has little significance. Low concentrations of aflatoxin have also been found in head scab-affected wheat in the USA (Hagler et al. 1984). Aflatoxin contamination of wheat is not regarded as a major problem, and only a low degree of contamination was found in mouldy bulk Queensland wheat which had sustained extensive water damage (Blaney 1986).

Table 3. Concentrations of pink grains, zearalenone and 4-deoxynivalenol in pooled samples of wheat harvested in 1983

\begin{tabular}{|c|c|c|c|c|c|}
\hline Depot & Sample & $\begin{array}{c}\text { Sample } \\
\text { weight } \\
(\mathrm{kg})\end{array}$ & $\begin{array}{c}\text { Pink } \\
\text { kernels } \\
(\%)\end{array}$ & $\begin{array}{l}\text { Zearalenone } \\
\left(\mathrm{mg} \mathrm{kg}^{-1}\right)\end{array}$ & $\begin{array}{l}\text { 4-Deoxynivalenol } \\
\left(\mathrm{mg} \mathrm{kg}^{-1}\right)\end{array}$ \\
\hline Forest Hill & $\begin{array}{l}\text { GP Cook } \\
\text { GP Banks } \\
\text { GP Kite } \\
2 \mathrm{H} \text { all } \\
\text { ASW all }\end{array}$ & $\begin{array}{l}6.8 \\
1.9 \\
1.6 \\
6.6 \\
3.7\end{array}$ & $\begin{array}{l}0.04 \\
0.05 \\
0.10 \\
0.01 \\
0.00\end{array}$ & $\begin{array}{l}\mathrm{A} \\
\mathrm{A} \\
\mathrm{A} \\
\mathrm{A} \\
\mathrm{A}\end{array}$ & $\begin{array}{l}0.11 \\
0.07 \\
0.07 \\
0.09 \\
0.05\end{array}$ \\
\hline Warwick & $\begin{array}{l}\text { GP Kite } \\
\text { GP Cook }\end{array}$ & $\begin{array}{l}5.3 \\
1.9\end{array}$ & $\begin{array}{l}0.22 \\
0.02\end{array}$ & $\stackrel{0.04}{A}$ & $\begin{array}{l}1.7^{\mathrm{B}} \\
0.10\end{array}$ \\
\hline Allora & GP all & 2.0 & 0.01 & A & 0.14 \\
\hline Clifton & $\begin{array}{l}\text { GP Kite } \\
\text { GP Cook } \\
\text { GP other }\end{array}$ & $\begin{array}{l}4.7 \\
4.3 \\
3.3\end{array}$ & $\begin{array}{l}0.01 \\
0.01 \\
0.04\end{array}$ & $\begin{array}{l}\mathrm{A} \\
\mathrm{A} \\
\mathrm{A}\end{array}$ & $\begin{array}{l}0.06 \\
0.02 \\
0.11\end{array}$ \\
\hline Byee & GP all & 3.5 & 0.01 & A & 0.01 \\
\hline Kingaroy & $\begin{array}{l}\text { GP all } \\
2 \mathrm{H} \text { all } \\
\text { ASW all }\end{array}$ & $\begin{array}{r}3.7 \\
2.8 \\
10.5\end{array}$ & $\begin{array}{l}0.01 \\
0.00 \\
0.00\end{array}$ & $\begin{array}{l}\mathrm{A} \\
\mathrm{A} \\
\mathrm{A}\end{array}$ & $\begin{array}{l}0.03 \\
0.06 \\
0.01\end{array}$ \\
\hline Wooroolin & $\begin{array}{l}\text { GP Cook } \\
\text { GP Banks } \\
\text { GP other } \\
2 \mathrm{H} \text { all } \\
\text { ASW Cook } \\
\text { ASW other }\end{array}$ & $\begin{array}{r}4.6 \\
4.1 \\
1.5 \\
1.2 \\
14.1 \\
8.2\end{array}$ & $\begin{array}{l}0.01 \\
0.04 \\
0.03 \\
0.01 \\
0.00 \\
0.00\end{array}$ & $\begin{array}{l}\mathrm{A} \\
\mathrm{A} \\
\mathrm{A} \\
\mathrm{A} \\
\mathrm{A} \\
\mathrm{A}\end{array}$ & $\begin{array}{l}0.02 \\
0.03 \\
0.05 \\
0.01 \\
0.01 \\
\mathrm{C}\end{array}$ \\
\hline Gayndah & $\begin{array}{l}\text { GP Cook } \\
\text { GP other } \\
2 \mathrm{H} \text { all } \\
\text { ASW all }\end{array}$ & $\begin{array}{r}10.1 \\
1.1 \\
10.7 \\
2.6\end{array}$ & $\begin{array}{l}0.01 \\
0.03 \\
0.00 \\
0.00\end{array}$ & $\begin{array}{l}\text { A } \\
\text { A } \\
\text { A } \\
\text { A }\end{array}$ & $\begin{array}{l}\mathrm{D} \\
\mathrm{C} \\
\mathrm{C} \\
\mathrm{C}\end{array}$ \\
\hline
\end{tabular}

A Zearalenone concentrations $<0.01 \mathrm{mg} \mathrm{kg}^{-1}$.

${ }^{B}$ Assayed by HPLC method. Others assayed by GC-MS method.

$C_{\text {Trace of }}$ 4-deoxynivalenol detected, $<0.01 \mathrm{mg} \mathrm{kg}^{-1}$.

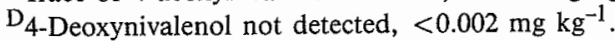

Although this investigation has shown a high frequency of mycotoxin contamination, several aspects must be emphasized. Firstly, the samples with higher concentrations were of the lowest grade of wheat, used predominantly for animal feed and manufacturing. Secondly, the surveys involved wheat from only the wetter districts where head scab is significant, and there is no reason at present to suspect significant contamination in wheat from other Queensland regions, where the bulk of wheat is grown. Thirdly, the surveys included the 1983 season, in which the degree of weather damage of wheat was unusually high. Routine monitoring of bulk wheat for DON and ZEA does not seem to be justified at present, but an increased incidence of head scab could change this situation. 
Table 4. Concentrations of pink grains, zearalenone and 4-deoxynivalenol in pooled samples of GP grade wheat harvested in 1984 and 1985

\begin{tabular}{llcll}
\hline Depot & $\begin{array}{c}\text { Sample } \\
\text { wt }(\mathrm{kg})\end{array}$ & $\begin{array}{c}\text { Pink } \\
\text { kernels }(\%)\end{array}$ & $\begin{array}{c}\text { Zearalenone 4-Deoxynivalenol } \\
\left(\mathrm{mg} \mathrm{kg}^{-1}\right)\end{array}$ & $\begin{array}{l}\text { (mg kg } \\
\text { Harvested } 1984\end{array}$ \\
\hline Forest Hill & 1.1 & 0.00 & $\mathrm{~A}$ & 0.07 \\
Pinkenba & 1.8 & 0.01 & $\mathrm{~A}$ & $\mathrm{C}$ \\
Warwick, Allora & 3.0 & 0.00 & $\mathrm{~A}$ & $\mathrm{C}$ \\
Kingaroy, Wooroolin & 1.3 & 0.00 & $\mathrm{~A}$ & 0.02 \\
& & Harvested 1985 & & \\
Forest Hill & 1.5 & 0.35 & 0.10 & 0.04 \\
Pinkenba & 1.2 & 0.19 & 0.01 & 0.34 \\
Warwick & 0.6 & 1.44 & 0.03 & $0.78^{\mathrm{B}}$ \\
Allora & 0.3 & 0.00 & $\mathrm{~A}$ & 0.12 \\
Clifton, Byee & 2.5 & 0.00 & $\mathrm{~A}$ & 0.02 \\
Kingaroy & 1.0 & 0.00 & $\mathrm{~A}$ & $\mathrm{D}$ \\
Wooroolin & 1.3 & 0.00 & $\mathrm{~A}$ & $\mathrm{D}$ \\
Gayndah & 1.5 & 0.00 & $\mathrm{~A}$ & 0.09 \\
\hline
\end{tabular}

\footnotetext{
A Zearalenone concentrations $<0.010 \mathrm{mg} \mathrm{kg}^{-1}$.

${ }^{B}$ Assayed by HPLC method. Others assayed by GC-MS method.

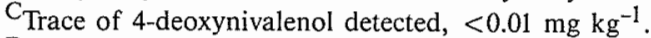

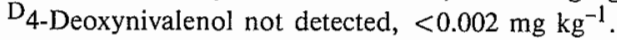

\section{Acknowledgments}

The Australian Wheat Board collaborated in this investigation by providing the samples and financial support. We are also grateful to Dr R. L. Dodman of this Department, for the isolations of $F$. graminearum from wheat grains and to Mr B. Clarke, New South Wales Department of Agriculture, Casino, for information on the occurrence of head scab in northern New South Wales.

\section{References}

Blaney, B. J. (1984). Mycotoxins in crops: epidemiological aspects in Queensland. In 'Plant Toxicology'. Proceedings of the Australian - USA. Poisonous Plants Symposium. Brisbane, Australia, May 14-18, 1984. (Eds A. A. Seawright, M. P. Hegarty, L. F. James and R. F. Keeler.) pp. 578-88. (The Queensland Poisonous Plants Committee: Animal Research Institute, Yeerongpilly, Qld.)

Blaney, B. J. (1986). Mycotoxins in water-damaged and mouldy wheat from temporary bulk stores in Queensland. Aust. J. Agric. Res. 37, 561-5.

Blaney, B. J., Bloomfield, R. C., and Moore, C. J. (1984a). Zearalenone intoxication of pigs. Aust. Vet. J. 61, 24-7.

Blaney, B. J., Moore, C. J., and Tyler, A. L. (1984b). Mycotoxins and fungal damage in maize harvested during 1982 in Far North Queensland. Aust. J. Agric. Res. 35, 463-71.

Blaney, B. J., Ramsey, M. D., and Tyler, A. L. (1986). Mycotoxins and toxigenic fungi in insect-damaged maize harvested during 1983 in Far North Queensland. Aust. J. Agric. Res. 37, 235-44.

Burgess, L. W. (1985). Mycotoxigenic species of Fusarium associated with grain diseases in eastern Australia. In 'Trichothecenes and Other Mycotoxins'. (Ed. J. Lacey.) pp. 15-19. (John Wiley and Sons: Chichester.)

Burgess, L. W., Dodman, R. L., Pont, W., and Mayers, P. (1981). Fusarium diseases of wheat, maize and grain sorghum in eastern Australia. In 'Fusarium: Diseases, Biology and Taxonomy'. (Eds P. E. Nelson, T. A. Tousson and R. J. Cook.) pp. 64-76. (The Pennsylvania State University Press: University Park and London.)

Francis, R. G., and Burgess, L. W. (1977). Characteristics of two populations of Fusarium roseum 'Graminearum' in eastern Australia. Trans Br. Mycol. Soc. 68, $421-7$. 
Hagler, W. M., Tyczkowska, K., and Hamilton, P. B. (1984). Simultaneous occurrence of deoxynivalenol, zearalenone and aflatoxin in 1982 scabby wheat from the midwestern United States. Appl. Environ. Microbiol. 47, 151-4.

Kurtz, H. J., Nairn, M. E., Nelson, G. H., Christensen, C. M., and Mirocha, C. J. (1969). Histologic changes in the genital tracts of swine fed estrogenic mycotoxin. Am. J. Vet. Res. 30, 551-6.

Moore, C. J., Blaney, B. J., Spencer, R. A., and Dodman, R. L. (1985). Rejection by pigs of mouldy grain containing deoxynivalenol. Aust. Vet. J. 62, 60-2.

Rees, R. G., Martin D. J., and Law, D. P. (1984). Black point in bread wheat: effects on quality and germination, and fungal associations. Aust. J. Exp. Agric. Anim. Husb. 24, 601-5.

Scott, P. M. (1983). Trichothecene problems in Canada. In 'Trichothecenes: Chemical, Biological and Toxicological Aspects'. (Ed. Y. Ueno.) pp. 218-20. (Elsevier Science Publishers: Amsterdam.)

Scott, P. M., Lau, P. Y., and Kanhere, S. R. (1981). Gas chromatography with electron capture and mass spectrometric detection of deoxynivalenol in wheat and other grains. J. Assoc. Off. Anal. Chem. 64, 1364-71.

Trenholm, H. L., Hamilton, R. M. G., Friend, D. W., Thompson, B. K., and Hartin, K. E. (1984). Feeding trials with vomitoxin (deoxynivalenol)-contaminated wheat: effects on swine, poultry and dairy cattle. J. Am. Vet. Med. Associ. 185, 527-31.

Tio, M., Burgess, L. W., Nelson, P. E., and Toussoun, T. A. (1977). Techniques for the isolation, culture and preservation of the Fusaria. Australas. Plant Pathol. Soc. Newsl. 6, 11-13.

Vesonder, R. F. (1983). Natural occurrence in North America. In 'Trichothecenes: Chemical, Biological and Toxicological Aspects'. (Ed. Y. Ueno.) pp. 210-17. (Elsevier Science Publishers: Amsterdam.)

Ware, G. M., Carman, A., Francis, O., and Kuan, S. (1984). Gas chromatographic determination of deoxynivalenol in wheat with electron capture detection. J. Assoc. Off. Anal. Chem. 67, 731-4.

Yoshizawa, T. (1983). Red-mold diseases and natural occurrence in Japan. In 'Trichothecenes: Chemical, Biological and Toxicological Aspects'. (Ed. Y. Ueno.) pp. 195-209. (Elsevier Science Publishers: Amsterdam.)

Manuscript received 13 April 1987, accepted 9 July 1987 